\title{
COMPARATIVE EFFICIENCY OF NEW INSECTICIDE FORMULATIONS AGAINST TOMATO LEAFMINER, Tuta absoluta, MEYRICK (LEPIDOPTERA: GELECHIIDAE) IN EGYPT
}

Mashtoly, T. A. ${ }^{1}$ and Nesreen A.S. Helal ${ }^{2}$

1-Dept. of Plant Protec., Fac. of Agric. Ain Shams Univ., Cairo, Egypt.

E-mail: telmashtoly@agr.asu.edu.eg

2-Dept. of Horticulture, Fac. of Agric. Ain Shams Univ., Cairo, Egypt.

Email: nesreenas@hotmail.com

\begin{abstract}
Tomato plants are the second most important vegetable crop grown in Egypt. Larvae of the tomato leafminer, Tuta absoluta, Meyrick are the most important and destructive pest of tomato, capable of causing up to $100 \%$ of tomato yield loss in some regions. Effectiveness of chemical control of T. absoluta is limited due to the insect's nature of damage as well as its rapid capability to develop resistance to diverse insecticides. A few synthetic pesticides have shown relative impact in decreasing field populations. However, these synthetic pesticides are not offered at economically affordable cost to many farmers. Two new formulations with more affordable cost, designed as Mash-T $15 \mathrm{EC}$ and Mash-V $25 \mathrm{EC}$ were prepared in our laboratory for control of T. absoluta. Physicochemical properties were in accordance with the FAO/WHO specifications 2010. Bioassay of commonly used pesticides against T. absoluta in Egypt, including Coragen ${ }^{\circledR} 20$ SC (Chlorantraniliprole), Avaunt ${ }^{\circledR} 15$ EC (Indoxacarb), and Proclaim ${ }^{2} 5$ WDG (Emamectin benzoate) in comparison with Mash-T and Mash-V against L2/L3 larvae using impregnated romaine lettuce leaves in leaf dipping technique was done. Results support that Chlorantraniliprole was the most effective formulation against T. absoluta larvae, followed by Mash-V. Mash-T and Indoxacarb had moderate activity levels, but emamectin benzoate showed low levels of activity at affordable concentrations. Statistical analyses did not detect any significant differences at $\mathrm{LC}_{50}$ level between Chlorantraniliprole and Mash-V, or between Indoxacarb and Mash-T. However, significant differences were found between emamectin benzoate and other tested pesticides.
\end{abstract}

Keywords: Tomato leafminer, Tuta absoluta, Bioassay, Efficiency, Insecticides.

\section{INTRODUCTION}

Tomato (Lycopersicon esculentum) is the second most important vegetable crop next to potato. World production of tomatoes is about 123.032.774 million tons fresh fruit produced on 3.7 million hectares. Tomato production has been reported for 144 countries (FAOSTAT Database, 2010). Tomato is one of the most important "protective foods" because of its special nutritive value. It is one of the most versatile vegetable with wide usage for soup, pickles, ketchup, puree, sauces and in many other ways it is also used as a salad vegetable. Tomato has very few competitors in the value addition chain of processing.

In Egypt, Tomato is the most important vegetable crop grown, with total annual planted area at approximately 251838 ha at 2009 (FAOSTAT Database, 2010). The harvested planted area with tomatoes was decreased with about $14.1 \%$ in one year to be $216385 \mathrm{ha}$ at 2010 . Therefore the total producing was sequentially declined about $16.9 \%$ from of 10.278539 at 2009 to 8.544990 millionton representing productivity about 39.49 ton/ha at 2010 after 40.81 ton/ha at 2009, Tomato leafminer has been considered the most destructive reason to harvested tomatoes area which diminish it for about $15.4 \%$ at 2013. Egypt is occupying the Fifth producer of tomatoes over the world and it produces $6.95 \%$ of tomatoes world production. In Egypt, tomato production is about55.88\% of total vegetative production in Egypt (FAOSTAT Database, 2015). Tomato plants are liable to attack with many key pests amongst is tomato leafminer, $T$. absoluta that proved one of the most important and destructive pests in so many countries over the world. The tomato leafminer, Tuta absoluta (Meyrick 1917) (Lepidoptera:
Gelechiidae), is one of the most devastating insect pests for tomato production. This leafminer also attacks other Solanaceae crops such as potatoes. It is originated from South America and has been mentioned in literature since about 45 years ago (Bahamondes and Mallea 1969). Recently it has been considered the most threat to tomatoes production in the Mediterranean region since it has the potential to spread to Spain (Urbaneja et al. 2007) and then other European countries such as: France (EPPO 2009a / article47), Italy (EPPO 2010/article 303), Malta (EPPO 2009d / article395), Netherlands (EPPO 2009b/article 255) and the United Kingdom, (EPPO 2009c/article 340). It was not hard for this cosmopolitan and highly adapted pest, Tuta absoluta, to invade North African countries such as Algeria, Morocco, Tunisia (Desneux et al. 2010). This invasive insect has the capability tocross the boarders and devastate tomato production both protected and open fields (http://www. tutaabsoluta.com). Thus, at the end of 2009 Tuta absolutahas been detected in tomato fields in Egypt and we believe that it came across the Mediterranean Sea or across the border from Libya. Since 2010 T. absoluta was becoming a cosmopolitan pest with no preventive breaks. The tomato leafminer has the capability to attack tomato plants in three levels started with mine the young leaves and then penetrate the stems and branches and then piercing flowers and fruits. This unique behavior affects the crop directly, producing losses between 60 and $100 \%$ of the total production (Ca'ceres 1992; Cely et al. 2006). It is extremely difficult to control once it has established itself in the ecosystem. It has a high reproductive potential, with up to 12 generations per year (De Vis et al. 2001; Ve'lez 1997) but this may vary among countries and the original climate. 
T. absoluta is a very challenging pest to control. Effectiveness of chemical control is limited due to insect's nature of damage as well as its rapid capability of development of insecticide resistant strains. The use of biological factors are still largely under development and not ready to combat this pest effectively and in a cost effective way. Sex pheromone trap is using as an early detection tool. Mass trapping and lure and Kill application of pheromone has been found to be effective to decrease the population of T. absoluta. IPM strategies are being developed to control T. absoluta. Various active substances can be applied in combination with bio-rational control tactics (http://www. tutaabsoluta.com).

Last five years, while there was no highly effective management tools for the leafminer, farmers tend to intensive use of chemical insecticides to the extent of frequent use every day which may cause adverse environmental effects including water pollution, eradication of beneficial wildlife and human health problems (Estay and Bruna 2002; Lietti et al. 2005, Desneux et al. 2007;) and for surethey develop resistance mechanisms to existing recommended insecticides.For these reasons, there is great interest to find efficient, economical control alternatives that allow sustainable tomatoes production.

The objectives of this study were to determine the efficiency of common used insecticides to control T. absoluta, such as Coragen ${ }^{\circledR} \quad 20 \quad$ SC (Chlorantraniliprole), Avaunt ${ }^{\circledR} 15$ EC (Indoxacarb), and Proclaim ${ }^{\circledR} 5$ WDG (Emamectin benzoate) in comparison with two new lap prepared formulations Mash-T 15 EC and Mash-V 25 ECunder laboratory bioassays.

\section{MATERIALS AND METHODS}

Preparation of formulations: two new formulations were designated as Mash-T 15 EC and Mash-V 25 EC at the Research and Development Center of Eid Company for manufacturing technical grade pesticides, Quwesna, Menoufia, Egypt.Lambda-Cyhalothrin TC 97\% and Chlorpyrifos TC96\% and Emamectin benzoate TC 70\% and Abamectin TC 97\% were used to prepare both formulations.Inert Surfactant mixture Ionic and Non-ionic emulsifier, spreading agents, organic hydrocarbon silicon as synergistic agent were used as adjuvant (Imported from China). The differences between both formula Mash- $\mathrm{T}$ and Mash- $\mathrm{V}$ were in the active ingredient matrix used, concentrations and types of adjuvant used. Mash- T formula is consisted of $6.2 \%$ Lambda-Cyhalothrin, 3.6\% Abamectin, 5.2\% of Emamectin benzoate, $20 \%$ inert surfactants and adjuvants and $65 \%$ solvents. Matrix ingredient of Mash$\mathrm{V}$ formula consisted of $8.7 \%$ of Lambda-Cyhalothrin, $6.3 \%$ Chlorpyrifos, 5.4\% Abamectin, 4.6\% Emamectin benzoate and $25 \%$ inert surfactant and Adjuvant and 50 $\%$ solvents. Each formula were subjected to determine the emulsion stability test as indicator for the physicochemical properties.

Physicochemical properties: new prepared tested formulations were subjected to determine the physicochemical properties according to FAO/WHO specifications 2010. Persistent foam of each tested pesticides and free oil portions were measured according to CIPAC F 2012 MT75 and MT 47.1 respectively.

Emulsion stability test: (FAO/WHO Specification 2010 and CIPAC MT 36.3 2012). Emulsion stability for the new lab-mad formulations, Mash-V and Mash-T was measuredusing three types of water, soft,hard and tap water. Hard water was prepared by dissolving $0.304 \mathrm{~g}$ of anhydrous calcium chloride and $0.139 \mathrm{~g}$ of magnesium chloride hexahydrate in double distilled water and made up to one liter. This provides total hardness equivalent to $342 \mathrm{ppm}$ of calcium carbonate. Soft water was prepared by mixing one volume of hard water with five volumes of double distilled water to provide water hardness of $57 \mathrm{ppm}$ according to CIPAC MT 73 (2012). Emulsion stability test was carried out using $100 \mathrm{ml}$-glass graduated stopper tubes, three tubes for each tested pesticide, one tube was filled with freshly prepared hard water, Second tube was filled with freshly prepared soft water and the third was filled with freshly tap water up to level $95 \mathrm{ml}$, calculated EC pesticides required to prepare $100 \mathrm{ml}$ was added. The tubes were up-settled to $180^{\circ}$ at the rate of complete cycle per $2 \mathrm{sec}, 30$ complete cycles were done. Separation or precipitation at either top or bottom of the graduated tube were measured and recorded after $0,0.5$, $2 \mathrm{hrs}$. and re-emulsification was done again after 24 and the stability was measured after 24.5 hour. Persistent foam was measured for each sample after $1 \mathrm{~min}$. of emulsification and detected free oil portions were measured and registered either after 2 and 24.5 hrs.(FAO/WHO specification 2010). Emulsion stability test was repeated thrice and three replicates for each.

Tested Pesticides: three different pesticides belong to three different chemical classes, Coragen ${ }^{\circledR}$ Chlorantraniliprole 20 SC belong to anthanilic diamid class and Avaunt ${ }^{\circledR}$ Indoxacarb 15 EC belong to oxadiazines were produced by DuPont Crop Protection Middle East \& Africa., Proclaim ${ }^{\circledR}$ Emamectin benzoate 5 WDG produced by Syngenta Egypt., were used in comparison to the lab-made formulations bioassay.

Bioassay: a leaf-dip bioassay technique was used to evaluate the susceptibility of L2/L3 larvae of $T$. absoluta to all tested formulations. Leaves of Romaine lettuce were placed individually in each tested concentration and in water for untreated (Control) for 30 seconds with gentle agitation, ensuring the entire surface is immersed equally and then allowed to air dry for $1 \mathrm{~h}$ and then supplied as the sole food source to larvae. Concentrations of 5, 10, 15, 20, 25 and $30 \mathrm{ppm}$ were used for testing the mortality of both Chlorantraniliprole and lab-mad formulation Mash-V. Concentrations of $30,40,50,60,70$ and 80 ppm were used for both Indoxacarb and lab-mad formulation Mash-T. Six concentrations of 40, 60, 80, 100, 120 and $140 \mathrm{ppm}$ were used for testing the bioactivity of Emamectin benzoate, all these concentrations were used after preliminary bracketing bioassays suggested them. The various diluted concentrations were applied in 100 $\mathrm{ml}$ of double distilled water and thoroughly vortexes 
before immersing the Romaine lettuce leaves. Control solutions consisted of double distilled water. Replicates consisted of a Petri dish (100 mm x $15 \mathrm{~mm})$ containing a lightly moistened filter paper, on to which half a leaf (dependent upon size) were placed and inoculated with about 20 L2/L3 stage larvae. These were maintained under controlled environmental conditions $\left(26 \pm 2{ }^{\circ} \mathrm{C}\right.$, $16 \mathrm{~L}: 8 \mathrm{D}$ photoperiod) and mortality was assessed after $48 \mathrm{~h}$. Larvae were counted as dead if when stimulated with a fine paintbrush, there was either no movement, or if movement was uncoordinated and they were unable to move a distance equal to double their body length. Each bioassay experiment was repeated thrice with three replicates of each concentration per experiment. Mortalities of each formulation were pooled and subjected to statistical data analysis.

Statistical Analysis: mortalities of every three experiments and three replicates in each were pooled together then subjected to Probit analysis using the Statistical Analysis System Version 9.4 program PROC PROBIT (SAS Institute 2012). Control mortalities (\%) were $8.8,4.4,6.6,7.7$ and 10 for the five tested pesticides, Chlorantraniliprole,Indoxacarb,Emamectin benzoate,Mash-T and Mash-V,respectively. When comparing $\mathrm{LC}_{50}$ values, a failure of $95 \%$ confidence limits to overlap was used as a measure to determine significant differences between treatments (Robertson and Preisler 1992). In all cases the likelihood ratio (L.R.) chi-square goodness-of-fit values indicated that the data adequately conformed to the probit model (Robertson and Preisler 1992).

\section{RESULTS AND DISCUSSION}

Persistence foam, free oil portions and emulsion stability\& re-emulsification values for the new lab-made formulations, Mash-T and Mash-V were in accordance with the FAO/WHO specifications 2010 (Table 1). After $1 \mathrm{~min}$. of the complete initial emulsification at zero time, persistence foam has been recorded as $9 \mathrm{ml}$ and $7 \mathrm{ml}$ for Mash-T and Mash-V respectively. Traces of oil were found on the top of emulsion after $2 \mathrm{~h}$ for both tested formula. However, the free oil has increased after re-emulsification at $24 \mathrm{~h}$ up to $0.3 \mathrm{ml}$ for Mash-T. Creamy layer was varied from 0.6 to $2.3 \mathrm{ml}$ and 0.5 to $1.4 \mathrm{ml}$ from $0 \mathrm{~h}$ to $24.5 \mathrm{~h}$. for Mash-T and Mash-V, respectively. Data of the emulsion stability were shown as a maximum average in between thrice trials at three replicates of each using CIPAC Standard Water A \& D. $\mathrm{LC}_{50}$ 's and $\mathrm{LC}_{90}$ 'sof eachpesticide were assessed after 48hrs, Toxicity index of each formulation was calculated according to the equation of Sun, 1950 where the standard is the most efficient formulation among tested ones. $\mathrm{LC}_{50}$, s of 13.3 Chlorantraniliprole, 14.7 Mash-V, 52.1 Indoxacarb, 47.5 Mash-T and 81.7 ppm of Emamectin benzoate.LC 90 $_{90}$ swere 32.8, 32.7, 85.7, 78.5 and $201.1 \mathrm{ppm}$ for Chlorantraniliprole, Mash-V, Indoxacarb, Mash-T and Emamectin benzoate, respectively (Table 2). Data emphasized that Chlorantraniliprole was the most effective pesticides with a lower $\mathrm{LC}_{50}$ and $\mathrm{LC}_{90}$ to $T$. absoluta followed by Mash-V. LC $_{90}$ of each of them was approximately close to the half value of $\mathrm{LC}_{50}$ of the other tested pesticide formulations. Emamectin benzoate was the lowest formulation in activity to the tested larvae. Failure of 95\% confidence limits to overlap was proofed thatthere were no significant differences shown up at $\mathrm{LC}_{50 \text { 's }}$ level between Chlorantraniliprole and Mash-V, or betweenIndoxacarb and Mash-T. However, significant differences were detected between Emamectin benzoate and other tested pesticides. No significant differences were shown upon $\mathrm{LC}_{90}$ 's among Chlorantraniliprole, Mash-V, Indoxacarb and Mash-T. However, significant difference is still obvious between all of them and Emamectin benzoate. Toxicity index values demonstrated a relative toxicity between the most efficient formulation (Chlorantraniliprole) as standard and other formulations (Table.2). Efficiency of Chlorantraniliprole to tomato leafminer larvae was approximately 4 fold of the efficacy of Indoxacarb and Mash-T. Meanwhile, it was more than 6 fold of the efficiency of Emamectin benzoate. Our data support that chlorantraniliprole was the most efficient formulation against $T$. absoluta larvae, followed by Mash-V. Chlorantraniliprole is registered for control of tomato pinworm on tomato in the United States (Dupont, 2008) due tocapability ofroot uptake, translocation in tomato plants and its privilegetranslaminar activity of tomato leaves and fruits. Lahm, 2009, reported that Chlorantraniliprole controls pest populations that are resistant to other insecticides. Mash-V has the potential to play a vital role in controlling tomato pests such as $T$. absoluta due to its unique matrix of composition. We believe that the bioactivity of Mash-V, which is statistically competing with Chlorantraniliprole, comes from the mixture of the active ingredient that shows a multi-mode of action, types of adjuvant and synergistic agents used. In Egypt, Tomato leafminer has been considered a catastrophic pest for tomato farmers since 2010. Cultivators have lost their yield up to $100 \%$ in the outbreak season of $T$. $a b s o l u t a$, and they have spent a lot of money in managing this devastating pest without any kind of output. The effective insecticides to this pest are really expensive to the Egyptian farmer. Mash-V is a promising formula at affordable economically cost. The non-judicious application of insecticides led to the development of resistance and may show a cross resistance (USDA, 2011). Tomato leafminer has acquired a resistance to many insecticides such as deltamethrin and abamectin (Lietti et al., 2005), Also resistant to cartap, abamectin, permethrin and methamidophos (Siqueira et al., 2000), and acephate and deltamethrin (Branco et al., 2001). So that it is the time for the newer insecticide classes that provideefficiency against the tomato leafminer (IRAC, 2009a), However, the modes of action need to be conserved by implementing resistance management. Rotation of controlling agents with different modes of action, usually provides a sustainable and effective approach to managing insecticide resistance (IRAC, 2009b). Indoxacarb is one of the newer insecticide classes and it is been considered of the reduced risk 
pesticide (EPA, 2000) that enters the insect through the cuticle or digestive system and acts by blocking sodium channels. Indoxacarb, spinosad, imidacloprid, deltamethrin, and Bacillus thuringiensisvar. kurstaki, were the most applied insecticidesin controlling $T$. absoluta in Spain (FERA, 2009; Russell IPM, 2009). Although, Chlorpyrifos, is not registered on tomato fruits in Italy, andthiacloprid, lufenuron are not registered on tomato fruits in Malta, and Metaflumizone is not registered on crops in Spain (MARM, 2010), they have been used as recommended pesticides in the outbreak infestation and/or with rotation of Pyrethrins in Italy (Garzia et al., 2009) or with sequence with Abamectin, Indoxacarb, Spinosad, Imidacloprid,and Bacillus thuringiensis (Btk) in Malta (Mallia, 2009). In Spain it was just for restricted period because existing control methods were insufficient to control T. absoluta in some regions of Spain (MARM, 2010). Although, Chlorpyrifos is banned for use on tomatoes in the United States (EPA, 2006) it is the most widely used pesticide in Egypt in controlling insect pests on vegetable crops. Indoxacarb is highly recommended foruse in France (FREDON-Corse, 2009) andin Brazil (IRAC, 2007) due to its selectively targets of lepidopteran pests and its efficacy in controlling outbreaks of tomato leafminer (Picanço, 2006; FERA, 2009; Sixsmith, 2009). Our results indicated that Indoxacarb and Mash-Thad moderate activity levels to the tested larvae of Tuta absoluta. This might explain how much the intensive and indiscriminate use of pesticides has been done in Egypt since 2010. Emamectin benzoate is highly potent to a broad spectrum of lepidopteran insect pests but it is about 8- to 15-fold less toxic to the serpentine leafminer, Liriomyza trifolii (Burgess) (Cox et al., 1995a\&b). Though, Emamectin benzoate has the potential to penetrates leaf tissues by translaminar movement and it has been recommended for control tomato leafminer in some countries such as Algeria (Gacemi and Guenaoui 2012) and in Greece (Roditakis et al., 2012) but it showed low levels of activity at affordable concentrations in our comparative bio efficiency to tomato leafminer, $T$. absoluta in Egypt. We believe each country should reevaluate the efficacy of the registered pesticide on Tomato crops routinely because this invasive pest, $T$. absoluta has an exponential development of resistance and it may vary among countries due to the legislation and the regulations of using pesticides and also this might be affected with the culture of each country and their way in dealing with the chemical compounds. While statistical analyses proved that there was no significant differences at $\mathrm{LC}_{50}$ level and Fiducial limits 95\% between Chlorantraniliprole and Mash-V, or betweenIndoxacarb and Mash-T. Significant differences were shown up between emamectin benzoate and each other tested pesticides. Our results trend support the use of either chlorantraniliprole or Mash-V individually or within a rotation to control $T$. absoluta and to delay resistance evolution. The individual use of Indoxacarb, Mash-T and emamectin benzoate is not recommended, but they may be used in programs to increase efficiency in controlling T. absoluta larvae. Integrated T. absoluta management is the best managing tool that count on different types of control not just pesticides and not just applied at the outbreak but it will be earlier.

Table 1. Emulsion stability and persistent foam of the new lab-made formulations, Mash-T 15\% EC and Mash-V $25 \%$ EC, using CIPAC standard waterat $30 \pm 2{ }^{\circ} \mathrm{C}$

\begin{tabular}{|c|c|c|c|}
\hline \multirow{2}{*}{\multicolumn{2}{|c|}{$\begin{array}{l}\text { Parameters } \\
\text { }{ }^{\mathrm{a}} \text { Persistence foam after } 1 \mathrm{Min} .\end{array}$}} & Mash-T 15\% EC & Mash-V $25 \%$ EC \\
\hline & & $9 \mathrm{ml}$ & $7 \mathrm{ml}$ \\
\hline \multirow{3}{*}{${ }^{\mathrm{b}}$ Emulsion Stability } & $\mathrm{Oh}$ & Complete emulsification & Complete emulsification \\
\hline & $0.5 \mathrm{~h}$ & Maximum Cream $0.6 \mathrm{ml}$ & Maximum Cream $0.5 \mathrm{ml}$ \\
\hline & $2.0 \mathrm{~h}$ & Maximum Cream $1.5 \mathrm{ml}$ & Maximum Cream 0.9 ml \\
\hline${ }^{\mathrm{c}}$ Free Oil & $2.0 \mathrm{~h}$ & Trace & Trace \\
\hline Re-Emulsification & $\begin{array}{c}24 \mathrm{~h} \\
24.5 \mathrm{~h}\end{array}$ & $\begin{array}{c}\text { Complete re-emulsification } \\
\text { Maximum Cream } 23 \mathrm{ml}\end{array}$ & $\begin{array}{c}\text { Complete re-emulsification } \\
\text { Maximum Cream } 1.4 \mathrm{ml}\end{array}$ \\
\hline Free oil & $24.5 \mathrm{~h}$ & $0.3 \mathrm{ml}$ & Trace \\
\hline
\end{tabular}

Table 2. Toxicity values of common used pesticides to Tuta absoluta in Egypt in comparison with the lab-mad formulations Mash-T $15 \%$ EC and Mash-V $25 \%$ EC

\begin{tabular}{|c|c|c|c|c|c|c|}
\hline Pesticide Formulation & $\mathbf{n}$ & Slope & $\begin{array}{c}\chi^{2} \\
(\mathbf{d f})^{c}\end{array}$ & $\begin{array}{c}\mathrm{LC}_{50}{ }^{\mathrm{ab}} \\
(95 \% \text { FL) }\end{array}$ & $\begin{array}{c}\mathrm{LC}_{90}^{\mathrm{ab}} \\
(95 \% \text { FL })\end{array}$ & $\begin{array}{l}\text { Toxicity } \\
\text { Index } \\
\end{array}$ \\
\hline $\begin{array}{l}\text { Chlorantraniliprole } \\
20 \% \text { SC }\end{array}$ & 1080 & $\begin{array}{c}3.2 \\
(0.69)\end{array}$ & $54.9(4)$ & $\begin{array}{c}13.3 \mathrm{a} \\
(8.3-18.6)\end{array}$ & $\begin{array}{c}32.8 \mathrm{a} \\
(22.2-108.8)\end{array}$ & 100 \\
\hline $\begin{array}{l}\text { Indoxacarb } \\
15 \% \text { EC }\end{array}$ & 1080 & $\begin{array}{c}5.9 \\
(1.05)\end{array}$ & $38.4(4)$ & $\begin{array}{c}52.1 \mathrm{~b} \\
(43.9-61.1)\end{array}$ & $\begin{array}{c}85.7 \mathrm{a} \\
(70.2-142.3)\end{array}$ & 25.5 \\
\hline $\begin{array}{l}\text { Emamectin benzoate } \\
5 \% \text { WDG }\end{array}$ & 1080 & $\begin{array}{c}3.3 \\
(0.43)\end{array}$ & $13.1(4)$ & $\begin{array}{c}81.7 \mathrm{c} \\
(77.1-105.3)\end{array}$ & $\begin{array}{c}201.1 \mathrm{~b} \\
(154.6-339.1)\end{array}$ & 16.3 \\
\hline $\begin{array}{l}\text { Mash-T } \\
15 \% \text { EC }\end{array}$ & 1080 & $\begin{array}{c}5.8 \\
(0.62)\end{array}$ & $13.7(4)$ & $\begin{array}{c}47.5 \mathrm{~b} \\
(42.9-51.8)\end{array}$ & $\begin{array}{c}78.5 \mathrm{a} \\
(69.3-96.2)\end{array}$ & 28 \\
\hline $\begin{array}{l}\text { Mash-V } \\
25 \% \text { EC }\end{array}$ & 1080 & $\begin{array}{c}3.7 \\
(0.75)\end{array}$ & $55.9(4)$ & $\begin{array}{c}14.7 \mathrm{a} \\
(9.9-20.2)\end{array}$ & $\begin{array}{c}32.7 \mathrm{a} \\
(22.9-92.6)\end{array}$ & 90.5 \\
\hline
\end{tabular}

${ }^{a} \mathrm{LC}_{50}$ 's and $\mathrm{LC}_{90}$ 's reported in ppm.

${ }^{b} \mathrm{LC}_{50}$ 's and $\mathrm{LC}_{90}$ 's followed by the same letter are not significantly different based on overlap of their $95 \%$ fiducial limits ( $P<0.05$ ). Each pesticide formulation was analyzed separately.

$c$ L.R. chi-square goodness-of-fit values. Tabular values at $P=0.05$ for $4 \mathrm{df}=9.49$

${ }^{d}$ Toxicity index (Sun, 1950) $=\left(\mathrm{LC}_{50}\right.$ of the most efficient compound (as Standard) $/ \mathrm{LC} \mathrm{C}_{50}$ of the other tested compound) $* 100$ 


\section{ACKNOWLEDGEMENTS}

We thank Eid Company for technical powders that used to prepare the lab-made formulations, Ahmed Abdullatif and Atif for technical assistance, Department of Plant Protection and Environmental and Toxicological research unit in Faculty of Agriculture, Ain Shams University for lab supplies and technical support.

\section{REFERENCES}

Bahamondes L., and A. Mallea (1969). Biologi'a en Mendoza de Scrobipalpula absoluta (Meyrick) Povolny (Lepidoptera-Gelechiidae),especie nueva para la República Argentina. Rev Facultad de Ciencias Agrarias, Universidad Nacional de Cuyo 15(1):96-104

Branco, M. C., F. H. França, M. A. Medeiros, and J. G. T. Leall (2001). Use ofinsecticides for controlling the South American tomato pinworm and thediamondback moth: a case study. Horticultura Brasileira 19(1):60-6.

Ca'ceres, S. (1992) La polilla del tomate en Corrientes. Biologi'ay control. Estacio'n Experimental Agropecuaria Bella Vista, INTA, Argentina

Cely, L., F. Cantor, D. Rodri'guez, and J. Cure (2006). Niveles de daños ocasionados por diferentes densidades de Tuta absoluta (Lep-idóptera: Gelechiidae) en tomate bajo invernadero. Socolen Encuentroconla Entomologi'aenel EjeCafetero. XXXIII Congreso de Entomologi'a, Manizales, Colombia, 26-28 July

CIPAC. (2012). Collaborative International Pesticides Analytical Council http://www.cipac.org/Handbooks/handbook_f.htm.

Cox, D. L., A. L. Knight, D. G. Biddinger, J. A. Lasota, B. Pikounis, L. A. Hull, and R. A. Dybas (1995b). Toxicity and field efficacy of avermectins against codling moth (Lepidoptera: Tortricidae) on apples. J. Econom. Entomol. 88: 708-715

Cox, D. L., D. Remick, J. A. Lasota, and R. A. Dybas (1995a). Toxicity of avermectins to Liriomyza trifolii (Diptera: Agromyzidae) larvae and adults. J.Econom. Entomol, 88: 1415-1419

Desneux, N., A. Decourtye, and J.M. Delpuech (2007). The sublethal effects of pesticides on beneficial arthropods. Annu Rev Entomol 52:81-106

Desneux, N., E. Wajnberg, K.A.G. Wyckhuys, G. Burgio, S. Arpaia, C.A. Narváez-Vasquez, J. GonzalezCabrera, D.C. Ruescas, D.C. , E. Tabone, J. Frandon, J. Pizzol, C. Poncet, T. Cabello, and A. Urbaneja (2010). Biological invasion of European tomato crops by Tuta absoluta : ecology, geographic expansion and prospects for biological control. J. Pest Sci. 83:197-215

DeVis, R., L. Fuentes, H. Escobar, and R. Lee (2001). Manejo Integrado de Plagas y Enfermedades En: Producción de Tomate bajo Invernadero.Capi'tulo 5. Universidad de Bogota' Jorge Tadeo Lozano, CIAA, Colciencias, Bogota', pp 59-90
Dupont. (2008). DuPont ${ }^{\mathrm{TM}}$ Coragen ${ }^{\circledR}$ Insect Control Technical Bulletin

http://www2.dupont.com/Production_Agricultur e/en_US/assets/downloads/pdfs/K.14833_Corag en_Tech_Bulletin. pdf

EPA. (2000). Pesticide Fact Sheet: Name of Chemical: Indoxacarb. Issued October 30, 2000. Environmental Protection Agency, Washington, D.C.

EPA. (2006). Reregistration Eligibility Decision for Chlorpyrifos. U.S.Environmental Protection Agency Office of Pesticide Programs.

EPPO. (2009) chttps://gd.eppo.int/reporting/article-340

EPPO. (2009a). https://gd.eppo.int/reporting/article-47

EPPO. (2009b). https://gd.eppo.int/reporting/article-255

EPPO. (2009d). https://gd.eppo.int/reporting/article-395

EPPO. (2010). https://gd.eppo.int/reporting/article-303

Estay, P., and A. Bruna. (2002). Insectos y a'caros asociados al tomate en Chile. In: Estay P, Bruna A (eds) Insectos, a'caros y enfermed-ades asociados al tomate en Chile. Centro Regional de Inves-tigación INIA-La Platina, Santiago, pp 9-22

FAO and WHO specifications. (2010). Manual on development anduse of FAO and WHO specifications for pesticides Second revision of the First Edition. FAO/WHO Joint Meeting on Pesticide Specifications (JMPS), Rome, Italy. http://www.fao.org/fileadmin/templates/agphome/do cuments/Pests_Pesticides/PestSpecsManual.pdf

FAOSTAT Database (2015). http://faostat3.fao.org/browse/Q/*/E

FAOSTAT Database, (2010). http://faostat.fao.org/site/339/default.aspx

FERA. (2009). South American tomato moth Tuta absoluta. Food andEnvironment Research Agency, Department for Environment Food and Rural Affairs. http://www.fera.defra.gov.uk/plants/plantHealth/ pestsDiseases/documents/ppnTutaAbsoluta.pdf

FREDON-Corse (2009). Mesures de lutte contre Tuta absoluta. Fédération Régionale de Défense contre les Organismes Nuisibles de Corse.http://www.fredon-

corse.com/standalone/1/CE5Bk98q7hNOOAd4q o4sD67a .pdf

Gacemi, A. and Y. Guenaoui (2012). Efficacy of Emamectin Benzoate on Tuta absoluta Meyrick (Lepidoptera: Gelechiidae) infesting a protected tomato crop in Algeria. Academic Journal of Entomology, 5(1): 37-40.

Garzia, G. T., G. Siscaro, A. Colombo, and G. Campo (2009a). Reappearance of Tuta absoluta in Sicily. Rinvenuta in Sicilia Tuta absoluta.Informatore Agrario 65(4):71-71.

IRAC. (2007). Tomato leafworm resistance management practice in Brazil. IRAC (Insecticide Resistance Action Committee) News-Resistance Management News, Conferences, and Symposia (15) :3. http://www.iraconline.org/documents/index 15. pdf 
IRAC. (2009a). Tuta absoluta on the move. IRAC (Insecticide Resistance Action Committee) newsletter. http://www.iraconline.org/documents/eConnection_issue20a.pdf

IRAC. (2009b). IRAC Mode of Action Classification. IRAC (Insecticide Resistance Action Committee).http://www.iraconline.org/document s/MoA\%20classification_v6.3.3_28july09pdf

Laham, G. P., D. Cordova, and J. D. Barry (2009). New and selective ryanodinereceptor activators for insect control. Bioinorganic Medicinal Chemistry 17:4127-4133.

Lietti, M. M., E. N. Botto, and A. R. Alzogaray (2005). Insecticide resistant populations of Tuta absoluta (Meyrick) (Lepidoptera: Gelechii-dae). Neotrop Entomol 34:113-119

Mallia, D. (2009). Guidelines for the control and eradication of Tuta absoluta.Ministry for Resources and Rural Affairs, Plant Health Department,

Malta. http://www.agric.gov.mt/plant-healthdeptprofile? $1=1$

MARM. (2010). Resolución de autorizatión excepcional para lacomercialización de productos fitosanitarios para el control de Tuta absolutaen el cultivo de tomate. In: Ministra de Medio Ambiente y Medio Ruraly Marino--Dirección General de Recursos Agrícolas y GanaderosSecretaria. General de Medio Rural.

Picanço, M. C. (2006). IRAC-Brazil Update. IRM: Tuta absoluta in Tomatoes Phase III: Monitoring and Management. P. 8-15 in IRAC International Spring Meeting. IRAC International Edinburg, Scotland.

Robertson, J. L. and H. G. Preisler. (1992). Pesticide bioassay with arthropods. CRC Press Inc., Boca Raton, FL.
Roditakis, E.,C.Skarmoutsou, and M. Staurakaki. (2013). Toxicity of insecticides to populations of tomato borer Tuta absoluta (Meyrick) from Greece. Pest Manag Sci. 69 : 834-8

Russell, IPM Ltd. (2009). Tuta absoluta information network-News. Russell IPM Ltd. http://www.tutaabsoluta.com/agrinewsfull.php?n ews $=89$ \&lang=en

SAS Institute (2012). SAS version 9.4 Cary, NC

Sequeira, H. A., R. N. Guedes, and M.C. Picanco. (2000). Insecticide resistance in populations of Tuta absoluta (Lepidoptera: Gelechiidae). Agric For Entomol 23:431-434

Sixsmith, R. (2009). Call for integrated pest management as Mediterraneantomato pests spread to UK. Horticulture Week.http://www.hortweek.com/news/search/94 3628/Call-integrated-pest-managementMediterranean-tomato-pests-spread-UK/

Sun, Y.P., (1950). Toxicity index-An improved method of comparingthe relative toxicity of insecticides. J. Econ. Entomol 43, 45-53.

Tuta absoluta Information network. (2010). http://www.tutaabsoluta.com

Urbaneja, A., R. Vercher, V. Navarro, M. F. Garcı'a, and J.L. Porcuna. (2007). La polilla del tomate, Tuta absoluta. Phytoma. 194:16-23

USDA. (2011). Federal Import Quarantine Order for Host Materials of Tomato Leafminer, Tuta absoluta (Meyrick). SPRO\# DA-2011-12. United States Department of Agriculture, Plant Protection \& Quarantine http://www.aphis.usda.gov/import_export/plants /plant_imports/federal_order/downloads/2011/T uta\%20absoluta5-5-2011.pdf

Vélez, R. (1997). Plagas agri'colas de impacto econo'mico en Colombia: Bionomı'a y manejo integrado. Editorial Universidad de Antio-quia, Medell''n, pp 379-385

\footnotetext{
مقارنة كفاعة مستحضر ات حشرية حديثة ضد ناخرة أوراق الطماطم (رتبة حرشفية الأجنحة) في مصر

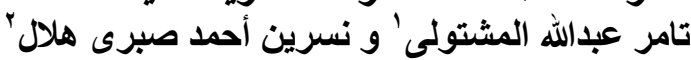

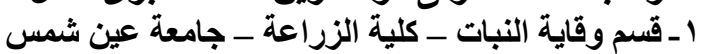

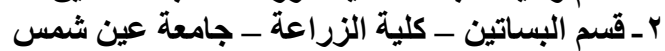

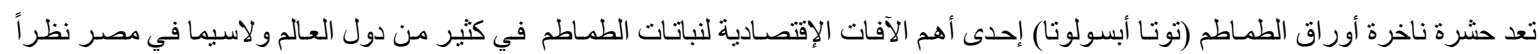

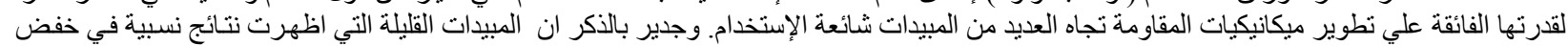

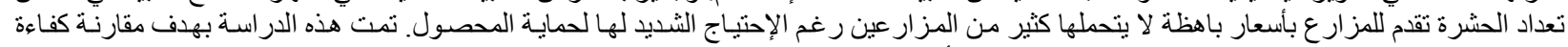

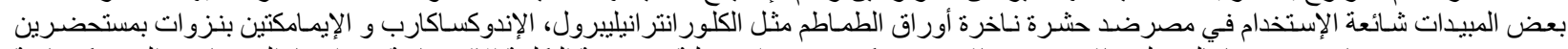

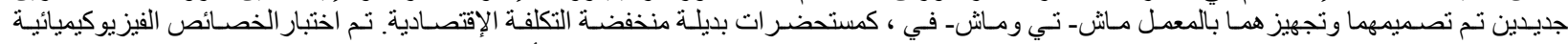

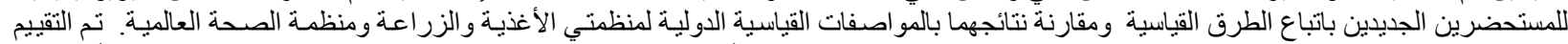

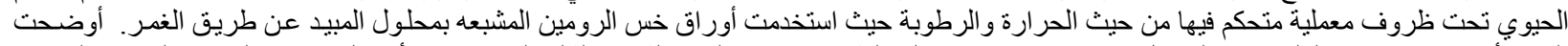

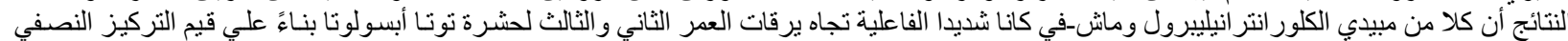

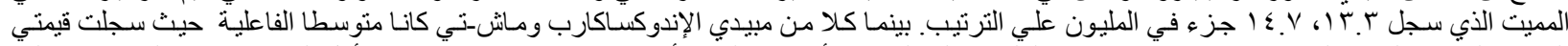

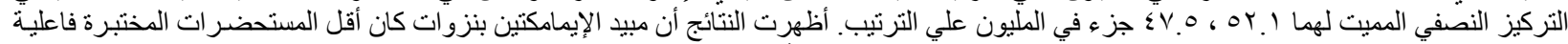

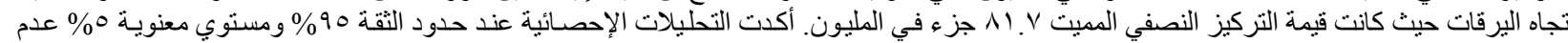

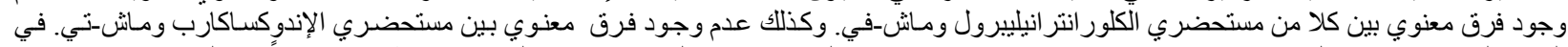

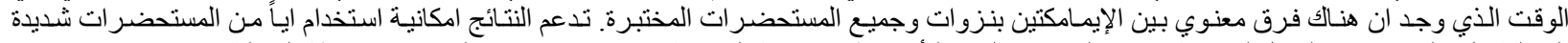

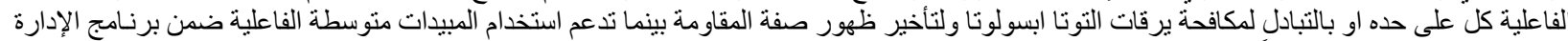

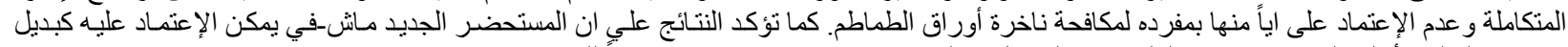

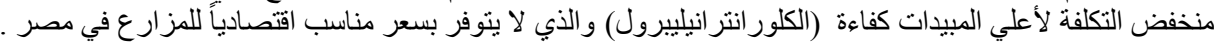


J. Plant Prot. and Path., Mansoura Univ., Vol.7 (3), 199-204, 2016 